\title{
POSISI TAWAR PERMENDIKBUD NOMOR 27 DAN URGENSI PENDIDIKAN AGAMA DALAM SATUAN PENDIDIKAN
}

\author{
Akil Fitra Sholakodin \\ Magister Sosiologi, Universitas Indonesia \\ Jalan Prof. Dr. Selo Soemardjan, Pondok Cina, Depok, Jawa Barat \\ e-mail: akil.fitra@ui.ac.id
}

\begin{tabular}{|c|c|c|c|c|c|}
\hline $\begin{array}{l}\text { Submitted } \\
2021-09-12\end{array}$ & $\begin{array}{c}\text { Accepted } \\
\text { 2021-12-02 }\end{array}$ & $\begin{array}{l}\text { Published } \\
\text { 2021-12-16 }\end{array}$ & open 2 Access & (c) (i) \& & a sinta 3 \\
\hline
\end{tabular}

\begin{abstract}
Abstrak
Permendikbud Nomor 27 Tahun 2016 merupakan kebijakan yang dibuat untuk memfasilitasi penganut aliran kepercayaan agar mendapatkan hak pendidikan beragama dan berkeyakinan. Namun, praktiknya masih ditemui banyak kendala yang menghambat implementasi kebijakan tersebut. Kendala-kendala terlihat dari aspek kelembagaan, layanan, dan pemahaman stakeholder terkait. Hal tersebut menimbulkan pertanyaan seberapa efektifkah mata pelajaran Pendidikan Agama bagi generasi muda. Kajian yang ditulis bertujuan untuk mengelaborasi efektivitas Pendidikan Agama yang praktiknya mengarahkan peserta didik menjadi lebih eksklusif, termasuk dalam hal pendidikan kepercayaan. Masalah tersebut apabila dibiarkan akan menimbulkan ekses negatif kedepannya. Penulis merekomendasikan perubahan ke arah yang inklusif dalam kerangka pendidikan multikultural.
\end{abstract}

Kata Kunci: aliran kepercayaan; multikulturalisme; Pendidikan Agama; Permendikbud Nomor 27.

\begin{abstract}
Minister of Education and Culture Regulation Number 27 of 2016 is a policy made to facilitate adherents of religious beliefs to get the right to education in religion and belief. However, in practice, there are still many obstacles that hinder the implementation of this policy. This obstacle can be seen from the institutional aspect, the service aspect, and the understanding aspect of the relevant stakeholders. This raises the question of how effective Religious Education subjects are for the younger generation in the current context. This paper aims to elaborate on the effectiveness of Religious Education which in practice directs students to be more exclusive, including in this case faith education. This problem if left unchecked will lead to negative excesses in the future. So this paper recommends a change to an inclusive direction within the framework of multicultural education.
\end{abstract}

Keywords: indigenous religion; multiculturalism; Religious Education; Permendikbud Number 27.

\section{PENDAHULUAN}

Permasalahan tentang diskriminasi pelayanan publik terhadap penganut aliran kepercayaan menimbulkan efek berkepanjangan. Masyarakat aliran kepercayaan kesulitan mengakses pelayanan-pelayanan publik yang diberikan pemerintah, seperti pada bidang sosial, budaya, hukum, dan pendidikan 
(Sholakodin, 2018). Khusus-pada masalah pendidikan, akses masyarakat penganut aliran kepercayaan masih kurang (Permana et al., 2021). Stigma negatif sebagai orang Liyan pada penganut aliran kepercayaan masih sangat kuat (Hernandi, 2016). Advokasi dan pengakuan dari pemerintah juga belum dirasakan atau dalam konteks lebih jauh, negara belum hadir pada pelayanan tersebut.

Kata kepercayaan adalah istilah untuk struktur teologi yang tidak termuat dalam formalisasi agama di Indonesia. Dahulunya istilah kebatinan lebih mainstream digunakan untuk mengenal penghayat, namun kebanyakan literatur menggunakan istilah kepercayaan atau kebatinan (Mutaqin, 2014). Hal tersebut terlihat dalam sejarah legitimasi konstitusional, penggunaan istilah kepercayaan dulu muncul mendahului istilah lainnya. Istilah tersebut pertama kali dikemukakan oleh KRMT Wongsonegoro dalam sidang BPUPKI pada 13 Juli 1945. Pemerintah membentuk Pengawas Aliran Kepercayaan Masyarakat (PAKEM) yang lebih dikenal sebagai aliran kepercayaan. Berdasarkan kosmologi pengetahuan masyarakat Jawa, beberapa istilah dapat digunakan sebagai identifikasi pada penghayat kepercayaan, diantaranya kebatinan, kejawen, dan klenik (Hamudy \& Rifki, 2020).

Pemerintah telah mengesahkan regulasi yang mengatur kehidupan penganut Aliran Kepercayaan, diantaranya Undang-Undang (UU) Nomor 23 Tahun 2006 yang diubah menjadi UU Nomor 24 Tahun 2013 tentang Adminduk dan memuat peraturan pelaksanaannya. Tahun 2009 muncul Surat Keputusan Bersama (SKB) Tiga Menteri Nomor 43 dan Nomor 41 tentang Pemberian Pelayanan kepada Ketuhanan Yang Maha Esa. Dilihat dari produk hukumnya, pelaksanaan hak warga negara untuk berkeyakinan tampaknya telah terlayani dengan baik, akan tetapi faktanya penganut aliran kepercayaan masih tereksklusi oleh oknum tertentu dari kelompok mayoritas (Adzkiya \& Fadhilah, 2020). Eksklusi pada penganut aliran kepercayaan berkaitan dengan pelayanan sipil, seperti pengurusan identitas kependudukan, pencatatan perkawinan, urusan sarana ibadah, dan pengurusan kematian.

Pemerintah melalui Direktorat Kepercayaan dan Masyarakat Adat (KMA) menerima laporan berupa diskriminasi pada peserta didik penghayat kepercayaan 
berkenaan dengan peminggiran hak-hak sipil berupa pelayanan administrasi kependudukan (Bustami, 2016). Diskriminasi yang diterima oleh peserta didik seperti pemaksaan untuk mengikuti pelajaran agama yang diakui negara dengan konsekuensi tidak naik kelas bila tidak dilakukan (Sholakodin, 2018). Guna mengatasi masalah tersebut, pada tahun 2016, Kemdikbud mengeluarkan aturan berupa Permendikbud Nomor 27 yang berisi pelayanan pendidikan kepercayaan peserta didik dengan latar belakang aliran kepercayaan setiap satuan pendidikan.

Seiring dengan diskriminasi yang telah diterima kelompok penghayat kepercayaan, juga menimbang tuntutannya dalam keseriusan pemerintah melayani kepentingan aliran kepercayaan, spesifik pada masalah pendidikan, maka pemerintah melalui Kemendikbud mengesahkan Permendikbud yang mengatur layanan mata pelajaran Pendidikan Kepercayaan pada setiap satuan pendidikan. Pengesahan Permendikbud Nomor 27 diharapkan dapat menghilangkan diskriminasi dan eksklusi yang dialami penghayat kepercayaan, terutama bidang pendidikan, sehingga eksistensi dan peran masyarakat penghayat kepercayaan lebih tampak dalam kehidupan bermasyarakat, berbangsa, dan bernegara.

\section{Permasalahan yang Dihadapi}

Permendikbud Nomor 27 Tahun 2016 merupakan langkah pertama untuk membuka jalan agar penghayat kepercayaan tidak hanya direkognisi dalam bidang pendidikan, namun juga sebagai pemenuhan hak sipil sebagai warga negara. Beberapa cara yang dilakukan oleh sekolah untuk mengakomodasi kebutuhan pelajaran Pendidikan Agama terhadap peserta didik penghayat kepercayaan dapat diklasifikasikan dalam 4 bentuk kemitraan, yaitu Kemitraan Konstruktivis, Kemitraan Adaptif, Kemitraan Partisipatif, dan Legal Formal Positivistif (Bustami, 2016). Bentuk kemitraan tersebut memiliki celah untuk perlakukan diskriminasi kepada peserta didik penghayat (Bustami, 2016; Suhadi et al., 2015).

Peserta didik difasilitasi sekolah untuk menyelenggarakan kebutuhan pembelajaran kepercayaan yang sesuai dengan kepercayaan yang dianut dengan adanya Permendikbud Nomor 27 Tahun 2016. Data dari Kemendikbud menunjukkan pada tahun 2016 terdapat 44.403 .499 peserta didik dengan total 
peserta didik penghayat "potensial" adalah sekitar 2 juta, sedangkan peserta didik penghayat yang sudah diakomodasi oleh negara sebanyak 2.651 peserta didik. Data menunjukkan bahwa banyak peserta didik dengan latar belakang aliran kepercayaan yang tidak terlayani dan tidak memiliki akses pendidikan. Implementasi Permendikbud Nomor 27 Tahun 2016 masih terdapat berbagai kendala, baik dalam pelaksanaan maupun dari penerimaan masyarakat (Hernandi, 2016). Permasalahan tersebut menjadikan Permendikbud Nomor 27 Tahun 2016 belum dilaksanakan secara baik dan belum mengatasi permasalahan diskriminasi peserta didik penghayat secara tuntas.

\section{Analisis Struktur, Kultur, dan Proses}

\section{Dinamika struktur}

Peraturan-peraturan yang berkaitan dengan kehidupan masyarakat penganut kepercayaan sudah banyak. Dinamika regulasi yang dibuat oleh pemerintah ditempatkan sebagai bentuk relasi kuasa serba negara, mulai dari urusan domestik sampai dengan urusan pelayanan yang bersifat umum. Rangkaian regulasi tersebut dijabarkan di Tabel 1. Secara historis, struktur akomodatif di masyarakat penghayat kepercayaan sebenarnya sudah dibentuk, namun pada masa bergantinya rezim Orde Lama ke Orde Baru tekanan struktur baru terjadi.

Saat periode perjuangan kemerdekaan, beberapa tokoh penghayat kepercayaan ikut serta dalam perjuangan kemerdekaan dan menyingkirkan penjajah, seperti beberapa tokoh terkenal BPU-PKI dan Panitia Persiapan Independen Indonesia, yaitu Wongsonagoro dan dr. Rajiman Wedyodiningrat. Para perintis memahami sepenuhnya sejarah dan keberadaan umat beragama, sehingga UUD 1945 memasukkan Pasal 29 yang dimaksudkan untuk memberikan payung bagi keyakinan akan adanya Tuhan Yang Maha Esa (Budijanto, 2016).

Pemerintah pada masa Orde Baru membuat peraturan perundang-undangan yang memberikan patronasi dan secara resmi mengakui adanya aliran kepercayaan mendapat tempat yang sama dan setara dalam semua ketentuan agama. Hal tersebut dituangkan dalam frasa keimanan yang mengikutinya dalam konstitusi, seperti TAP-MPR, GBHN, Repelita, UU yang mengatur Perkawinan, UU tentang 
Ormas, Keputusan Presiden, dan Instruksi Presiden. Pelaksanaannya sering kali tidak konsisten dan terdapat kelemahan.

Tabel 1 Deskripsi Struktur Akomodatif dan Eksklusif Regulasi Penghayat Kepercayaan

\begin{tabular}{|c|}
\hline Struktur Akomodatif \\
\hline 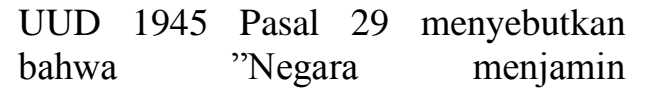 \\
\hline $\begin{array}{l}\text { kemerdekaan tiap-tiap warganya untuk } \\
\text { memeluk agama dan beribadah } \\
\text { menurut agama dan kepercayaan itu." }\end{array}$ \\
\hline Kata kepercayaan diusulkan oleh \\
\hline $\begin{array}{l}\text { Wongsonegoro dalam sidang BPUPKI } \\
\text { untuk merujuk pada Aliran }\end{array}$ \\
\hline Kepercayaan. \\
\hline $\begin{array}{l}\text { Peraturan bersama Menteri Dalam } \\
\text { Negeri serta Menteri Kebudayaan dan }\end{array}$ \\
\hline Pariwisata Nomor 40-42 Tahun 2009 \\
\hline $\begin{array}{l}\text { tentang Pedoman Pelestarian } \\
\text { Kebudayaan bahwa ruang lingkup } \\
\text { pelestarian budaya adalah juga memuat }\end{array}$ \\
\hline $\begin{array}{l}\text { Kepercayaan terhadap Tuhan Yang } \\
\text { Maha Esa. }\end{array}$ \\
\hline
\end{tabular}

Putusan MK Nomor 97/PUUXIV/2016 tentang Demi Keadilan Berdasarkan Ketuhanan Yang Maha Esa, yang mengabulkan gugatan masyarakat penghayat kepercayaan terhadap Pasal 61 ayat (1) dan (2) UU 23 Tahun 2006 juncto Pasal 64 ayat (1) dan (5) UU 24 Tahun 2013 tentang Adminduk yang menghasilkan aliran kepercayaan setara dengan agama.

Undang-Undang Republik Indonesia Nomor 20 Tahun 2003 tentang Sisdiknas Pasal 4 yang berbunyi penyelenggaraan pendidikan dilaksanakan secara demokratis dan berkeadilan, tidak mendiskriminasi serta menjunjung tinggi nilai keagamaan, kultural, HAM, dan kemajemukan bangsa.

Permendikbud Nomor 27 Tahun 2016 tentang pelayanan hak belajar pendidikan kepercayaan bagi peserta didik dengan latar belakang aliran kepercayaan setiap satuan pendidikan.

\section{Struktur Eksklusif}

UU Nomor 1 Tahun 1965 PNPS tentang

Pencegahan Penodaan Agama.

Penjabarannya merupakan hulu dari

eksklusi masyarakat penganut

kepercayaan.

Instruksi Menteri Agama Nomor 4 Tahun 1978 tentang Kebijakan Mengenai Aliran-Aliran Kepercayaan. Departemen Agama tidak lagi mengurusi aliran kepercayaan karena merujuk pada Ketetapan MPR Nomor IV/MPR/1978 tentang GBHN yang menyebutkan bahwa kepercayaan terhadap Tuhan Yang Maha Esa bukan merupakan agama sehingga naungannya di Departemen Kebudayaan dan Pariwisata.

Ketetapan MPR Nomor IV/MPR/1978 tentang GBHN yang menegaskan bahwa Kepercayaan kepada Tuhan Yang Maha Esa bukan merupakan agama.

Undang-Undang Nomor 14 Tahun 2005 yang mengatur syarat minimal tenaga pengajar dalam satuan pendidikan yaitu guru dan dosen.

Undang-Undang Nomor 20 Tahun 2003 tentang sistem pendidikan nasional yang menetapkan standar acuan kompetensi guru. 
Seperti halnya UU Nomor 1 Tahun 1965 tentang Penyimpangan pada Ajaran Pokok Agama yang isinya secara langsung mewajibkan semua warga negara untuk menganut agama resmi (Maarif et al., 2019). Apa yang terjadi juga menyebabkan tersingkirnya orang-orang yang beriman. Tekanan struktur di masyarakat penghayat kepercayaan kemudian berlanjut ketika negara mengeluarkan aturan yang memperjelas diskriminasi dan eksklusi terhadap kelompok penghayat kepercayaan. Aturan tersebut dikeluarkan dengan Instruksi Menteri Agama Nomor 4 Tahun 1978 tentang Kebijakan Mengenai Aliran-Aliran Kepercayaan yang dalam aturan tersebut negara memisahkan aliran kepercayaan dengan agama dan aliran kepercayaan kemudian dianggap sebagai kebudayaan. Tekanan tersebut kemudian menimbulkan dampak panjang. Tekanan didasarkan pada GBHN yang disusun oleh MPR mempertegas bahwa aliran kepercayaan bukan agama.

Setelah bertahun-tahun mendapatkan perlakuan diskriminatif dari negara, pada masa reformasi struktur-struktur yang ada dalam negara mulai akomodatif sejak disahkannya Permendikbud Nomor 27 Tahun 2016 yang mengatur hak-hak pendidikan penganut aliran kepercayaan. Legitimasi elemen struktur lain semakin menguat ketika Mahkamah Konstitusi memenangkan gugatan masyarakat aliran kepercayaan pada UU Adminduk yang secara langsung menyetarakan kedudukan aliran kepercayaan dengan agama. Permasalahan lain muncul, dalam muatan pendidikan secara struktur Permendikbud ternyata berlawanan dengan UU Nomor 20 Tahun 2003 tentang Sisdiknas serta UU Nomor 14 Tahun 2005 tentang Guru dan Dosen.

\section{Kultur}

Pengesahan Permendikbud Nomor 27 Tahun 2016 disambut baik oleh penghayat kepercayaan dan beberapa Lembaga Swadaya Masyarakat (LSM) yang berusaha membangun nilai toleransi, keadilan, dan multikuluralisme di Indonesia. Meskipun peraturan tersebut dinilai belum sempurna dan memiliki banyak kendala, akan tetapi terdapat kelompok-kelompok yang mengadvokasi kesetaraan 
untuk kaum minoritas. Hal tersebut merupakan langkah yang baik untuk mempromosikan nilai inklusi, keadilan, dan kesetaraan ke publik (Baskoro, 2020).

Regulasi Permendikbud Nomor 27 Tahun 2016 merupakan aturan yang lahir karena adanya desakan dari kelompok penghayat kepercayaan yang tereksklusi dari pemenuhan haknya pada aspek pendidikan (Sholakodin, 2018). Penghayat kepercayaan merasa perlu adanya pendidikan kepercayaan bagi generasi penerusnya untuk dapat memberikan pemahaman nilai-nilai luhur yang ditujukan untuk ketahanan nasional. Permendikbud Nomor 27 Tahun 2016 juga lahir dari upaya untuk menegakkan nilai kesetaraan, penghormatan kepada HAM, dan penghapusan diskriminasi (Budijanto, 2016). Titik nilai dari aturan tersebut adalah pemenuhan hak peserta didik untuk memeluk kepercayaan dan mengekspresikan kepercayaannya, serta pengejawantahan nilai-nilai kepercayaan untuk nasionalisme. Upaya menumbuhkan nilai-nilai tersebut pada pendidikan ternyata terkendala kultural.

\section{Respons masyarakat terhadap kebijakan}

Hasil kajian terdahulu memperlihatkan bagaimana peserta didik memandang teman sebayanya pemeluk penghayat kepercayaan di salah satu sekolah di Semarang, dengan hasil sebagai berikut: (1) $84 \%$ menyatakan bahwa seluruh peserta didik penghayat kepercayaan harus mendapatkan hak yang sama dengan peserta didik lainya dalam mendapatkan pendidikan; (2) $73 \%$ menyatakan bahwa peserta didik penghayat berhak mendapatkan mata pelajaran dan praktik religiositasnya di sekolah; (3) $73 \%$ menyatakan peserta didik dengan latar belakang aliran kepercayaan memiliki hak yang wajib dilindungi dan dimuat dalam kurikulum sekolah; (4) $61 \%$ menyatakan perlu diadakan mata pelajaran penghayat di sekolah; (5) 61\% menyatakan bahwa tidak adanya mata pelajaran bagi peserta didik penghayat kepercayaan adalah diskriminasi; (6) $59 \%$ menyatakan tidak terselenggaranya mata pelajaran bagi peserta didik penghayat adalah kekerasan; dan (7) 52\% menyatakan adil jika peserta didik penghayat tidak naik kelas karena tidak mengikuti mata pelajaran Agama sesuai dengan keyakinannya (Ramadhan, 2019). Hal tersebut menunjukkan bahwa secara 
normatif peserta didik mengakui dan menoleransi adanya peserta didik penghayat, namun tingkat kedalaman toleransi peserta didik bisa dilihat masih cukup rendah untuk bersimpati lebih jauh terhadap ketidakadilan yang dialami oleh teman sebayanya sebagai penganut penghayat kepercayaan (Ramadhan, 2019).

Hasil kajian menunjukkan bahwa kultur di sekolah tempat pendidikan berlangsung masih belum menerima akan hadirnya kebijakan tersebut. Meskipun sudah terdapat aturan Permendikbud Nomor 27 Tahun 2016 untuk melayani kebutuhan pendidikan penghayat kepercayaan, namun pelaksanaannya masih terdapat kendala, bukan hanya karena kurangnya fasilitas, pandangan dan stigma negatif dari warga sekolah lainnya terhadap peserta didik penghayat kepercayaan. Pandangan dan stigma negatif lahir dari peraturan pada masa Orde Baru yang menentukan bahwa kepercayaan selain lima agama resmi tidak dapat dimasukkan ke KTP karena dianggap aliran menyimpang mengikuti ajaran komunis. Kebijakan stuktural kemudian menumbuhkan stigma negatif di masyarakat terhadap penganut aliran kepercayaan (Maulana \& Setyowati, 2019).

Pelanggengan stigma sosial tidak hanya terjadi pada masa Orde Baru, beberapa kebijakan era reformasi seperti pasal-pasal pengosongan kolom agama dalam UU Adminduk Nomor 23/2006 dan Standar Operasional Prosedur Intelijen Kejaksaan, juga memberikan andil untuk melegitimasi dan melanggengkan stigma sosial di masyarakat. Hal tersebut menunjukkan adanya politik hukum untuk mengeksklusi dan membatasi gerak dari penghayat kepercayaan. Keadaan kultural tersebut berdampak pada enggannya beberapa penganut penghayat kepercayaan untuk menyatakan dirinya sebagai penghayat kepercayaan karena ketakutan dan trauma atas perlakuan masyarakat, sehingga ketakutan tersebut juga menjadi penghalang untuk mendapatkan perlindungan dan pelayanan kebutuhan sebagai penganut penghayat kepercayaan.

\section{Rekomendasi Pendidikan Agama Multikultural}

Pendidikan multikultural adalah pendidikan konseptual yang menekankan keragaman diatas kesetaraan. Pendidikan multikultural sebagai pendidikan tentang orang kulit berwarna yang berarti bahwa pendidikan multikultural ingin 
mengeksplorasi perbedaan sebagai kebutuhan dan bagaimana orang-orang yang dapat menanggapi perbedaan tersebut (Banks \& Banks, 2016). Pendidikan multikultural adalah gagasan proses yang mengubah struktur lembaga pendidikan dengan tujuan peserta didik berkebutuhan khusus dalam hal ras, suku, bahasa, dan semua budaya memiliki kesempatan yang sama untuk mengakses pendidikan yang layak. Pendidikan didasarkan pada keadilan sosial dan pemerataan pendidikan, serta berkomitmen untuk memfasilitasi proses pembelajaran yang dibutuhkan setiap peserta didik untuk mencapai potensi maksimalnya.

Dimensi dalam pendidikan multikultural yang terkait dengan orang lain, yaitu: (1) "Integrasi konten", yaitu integrasi seperti budaya dan kelompok untuk menggambarkan konsep dasar dan generalisasi teori; (2) "Equitable pedagogy", mengadaptasi pendidikan dengan pembelajaran peserta didik dengan tujuan memfasilitasi pencapaian akademik yang berbeda, baik ras, budaya, etnis, dan sosial; (3) dan "Sekolah Pemberdayaan Sosial dan Budaya", sekolah yang menyediakan metrik tentang keragaman ras, budaya, gender, serta kesetaraan.

\section{Kekuatan (Strengths)}

Pendidikan multikultural merupakan transisi yang membutuhkan waktu lama untuk mencapai tujuan dan sasarannya. Ide sentral pendidikan multikultural yaitu penyampaian rasa hormat, penghargaan, dan empati terhadap setiap individu yang berbeda secara agama dan budaya (Banks \& Banks, 2016). Beberapa kekuatan mendasar dari pendidikan multikultural dalam proses pendidikan bagi peserta didik, yaitu: (1) Memberikan fasilitas pada peserta didik terkait pemahaman dan pengetahuan tentang budaya berbagai etnis; (2) Memberikan pemahaman pada peserta didik bahwa setiap budaya yang dimiliki setiap etnis memiliki nilai yang sama; (3) Memberi akses yang sama terhadap setiap peserta didik tanpa mempersoalkan perbedaan etnis, ras, kelas sosial, dan latar belakang budaya yang berbeda; dan (4) Mengupayakan persamaan dan pemerataan pendidikan yang berupa arus utama dalam pemahaman guru sebagai fasilitator terhadap keragaman budaya yang berimplikasi pada perilaku mengajar, gaya belajar, dan penyelenggaraan pendidikan. 


\section{Kelemahan (Weaknesses)}

Pelaksanaan pendidikan multikultural sangat memungkinkan adanya kendala yang terjadi di sekolah. Beberapa hal perlu diantisipasi sejak awal, termasuk dalam konteks perbedaan arah kebudayaan. Perbedaan makna akan menimbulkan perbedaan dalam pelaksanaannya. Makna yang berbeda berimplikasi pada implementasi tindakan yang akan dilakukan. Apalagi dalam konteks multikulturalisme yang hanya dipandang sebagai konsepsi multietnis dan akar dari toleransi saja. Apabila di satuan pendidikan kondisi peseta didik yang ada hanya etnis homogen, maka orang merasa tidak perlu memberikan peserta didik pendidikan multikultural.

Arus utama pendidikan multikultural adalah pemahaman pada nilai-nilai kemanusiaan dan kebersamaan tanpa negosiasi apapun. Latar belakang peserta didik yang bermacam-macam etnis seharusnya menjadi modal sosial-kultural yang dapat menjadi nilai tambah pengetahuannya. Harapannya, dengan kondisi berikut, peserta didik dapat mengimplementasikan aspek multikulturalisme di sekolah dalam perilaku sosial di masyarakat.

\section{Peluang (Opportunities)}

Sikap primordialisme yang muncul di masyarakat Indonesia sangat mungkin terjadi, mengingat ragam suku, ras, agama, dan golongan yang banyak. Sisi negatifnya, apabila tidak dikelola dengan baik dapat menjalar pada munculnya konflik yang masif. Upaya menciptakan toleransi dan saling pengertian dalam dinamika kehidupan bangsa yang multikulturalis, perlu ditekankan penerapan sistem pendidikan yang mengarus utamakan pluralisme, berarti masuk dalam pendidikan multikultural.

\section{Masalah (Problem)}

Konsep dasar dan pemenuhan pendidikan multikultural masih sebatas wacana. Praktik pendidikan berbasis multikulturalisme yang ada di Indonesia belum bisa dilakukan secara ideal seperti di Amerika Serikat, walaupun secara kualifikasi memiliki indikator pluralis yang identik (Banks \& Banks, 2016). 
Persoalan tersebut disebabkan karena secara historis penyelenggaraan pendidikan lebih condong ke paradigma primitivisme. Contohnya dalam membentuk lembaga pendidikan selalu mengidentifikasikan dan mengasosiasikan ke konteks agama, kedaerahan, dan kolektivitas kelompok. Sistem pendidikan yang telah lama tersentralisasi juga memengaruhi perilaku dan tindakan manusia pada ranah pendidikan, implikasinya secara sederhana akan sulit bagi peserta didik yang dihasilkan untuk menghargai dan mengakui perbedaan yang muncul di lingkungan sekitarnya (Putri \& Pringgowijoyo, 2020).

Tabel 2 Hasil Analisis SWOPA Urgensi Pendidikan Agama di Sekolah

\begin{tabular}{|c|c|}
\hline Komponen & Uraian \\
\hline Strength & $\begin{array}{l}\text { Dukungan dari para kelompok pendidikan progresif yang melihat } \\
\text { Pendidikan Agama sebagai bentuk diskriminasi dan bias } \\
\text { mayoritas; } \\
\text { Mengedepankan nilai-nilai multikulturalisme, toleransi, dan } \\
\text { keadilan. }\end{array}$ \\
\hline Weakness & $\begin{array}{l}\text { Bertentangan TAP MPRS No. XXVII/MPRS/1966 yang } \\
\text { mewajibkan peserta didik untuk mengikuti pelajaran agama; } \\
\text { Bertentangan dengan UU Nomor } 20 \text { Tahun } 2003 \text { tentang Sistem } \\
\text { Pendidikan Nasional, hak mendapatkan Pendidikan Agama } \\
\text { diselenggarakan dalam bentuk pendidikan; } \\
\text { Pertentangan dari kelompok agama, terkhusus agama Islam karena } \\
\text { pelajaran agama ditempatkan sebagai pelajaran karakter dan moral } \\
\text { untuk menciptakan karakter peserta didik yang religius, } \\
\text { penghapusan Pendidikan Agama dinilai sebagai bentuk } \\
\text { sekulerisme; } \\
\text { Keberlanjutan guru agama yang ada di sekolah negeri. }\end{array}$ \\
\hline Opportunity & $\begin{array}{l}\text { Singapura dan Malaysia yang dapat dijadikan referensi dan acuan } \\
\text { untuk penghapusan mata pelajaran Pendidikan Agama. }\end{array}$ \\
\hline $\begin{array}{c}\text { Program } \\
\text { Action }\end{array}$ & $\begin{array}{l}\text { Penghapusan mata pelajaran Pendidikan Agama; } \\
\text { Melakukan penelitian dan telaah pelaksanaan pembelajaran agama } \\
\text { di sekolah; } \\
\text { Melakukan audiensi dengan para pemangku kepentingan; } \\
\text { Membuat policy brief tentang pelaksanan pendidikan agama di } \\
\text { sekolah negeri; } \\
\text { Membuat policy paper penghapusan Pendidikan Agama di sekolah } \\
\text { negeri. }\end{array}$ \\
\hline
\end{tabular}




\section{SIMPULAN}

Secara stuktural pendidikan agama adalah praktik diskriminasi kepada kelompok penghayat kepercayaan, diskriminasi tersebut berujung pada kekerasan dalam bentuk mengharuskan panganut aliran kepercayaan memanipulasi identitas. Struktur yang mengkristal kemudian mengkultur di masyarakat sehingga masyarakat memiliki stigma negatif terhadap penganut penghayat kepercayaan. Beberapa kasus menunjukkan perlakuan tidak baik dan diskriminasi kepada peserta didik penghayat yang dilakukan oleh guru dan teman-teman sekolah. Terdapat berbagai upaya kolektif seperti organisasi berbasis kepercayaan dan advokasi kebijakan yang memunculkan Permendikbud Nomor 27 Tahun 2016, namun usaha tersebut belum memberikan pelayanan yang adil bagi peserta didik penghayat. Adanya kebijakan lain yang masih diskriminasi dan kultur intoleran yang masih sangat kuat menyebabkan pelayanan yang adil dan inklusif sulit dilakukan. Salah satu langkah yang dapat dilakukan adalah mencabut aturan yang diskriminatif untuk mengatasi hal tersebut. Aturan tentang penyelenggaraan pendidikan agama perlu dihapuskan untuk mencabut salah satu praktik diskriminasi yang ada di sekolah, khususnya di sekolah negeri.

\section{DAFTAR PUSTAKA}

Adzkiya, U., \& Fadhilah, I. (2020). Inklusi Sosial Penghayat Kepercayaan: Upaya Mendorong Hak Warga Negara Penganut Kepercayaan Sedulur Sikep Kudus. At-Taqaddum, 12(1), 91-101. https://doi.org/10.21580/at.v12i1.5622.

Banks, J. A., \& Banks, C. A. M-G. (2016). Multicultural Education: Issues and Perspectives. Danvers: John Wiley \& Sons, Inc.

Baskoro, A. (2020). Mewujudkan Social Inclusion: Kontribusi Satunama terhadap Penghayat Kepercayaan di Yogyakarta. Panangkaran: Jurnal Penelitian Agama dan Masyarakat, 3(2), 181-196. https://doi.org/10.14421/panangkaran.2019.0302-03.

Budijanto, O. W. (2016). Penghormatan Hak Asasi Manusia bagi Penghayat Kepercayaan di Kota Bandung. Jurnal HAM, 7(1), 35-44. 
https://doi.org/10.30641/ham.2016.7.35-44.

Bustami, A. L. (2016). Kepercayaan terhadap Tuhan Yang Maha Esa dan Tradisi dalam https://kebudayaan.kemdikbud.go.id/ditkt/wp-content/uploads/sites/ 6/2016/11/SOSIALISASI-PERMENDIKBUD-NO.-27_2016-Tentang-

Layanan-Pendidikan-Kepercayaan-Tdp-Tuhan-Yme-Pd-Satuan-

Pendidikan.pdf. Diakses 1 September 2021.

Hamudy, M. I. A., \& Rifki, M. S. (2020). Civil Rights of the Believers of Unofficial Religions (Penghayat Kepercayaan) in Pekalongan District. Jurnal Antropologi: Isu-Isu Sosial Budaya, 22(1), 48-59. https://doi.org/10.25077/jantro.v22.n1.p48-59.2020.

Hernandi, A. (2016). Nilai-Nilai Ajaran Kepercayaan terhadap Tuhan YME sebagai Rujukan Pembentukan Karakter Bangsa dalam https://kebudayaan.kemdikbud.go.id/ditkt/wpcontent/uploads/sites/6/2016/09/Makalah-ANDRI-HERNANDI-Nilai-NilaiKepercayaan-terhadap-Tuhan-YME-menjadi-Rujukan-PembentukanKarakter-Bangsa.pdf. Diakses 1 September 2021.

Instruksi Menteri Agama Nomor 4 Tahun 1978 tentang Kebijakan Mengenai Aliran-Aliran Kepercayaan dalam https://www.anri.go.id/download/ inventaris-arsip-tekstual-departemen-agama-19501998-1630545394.

Diakses 1 September 2021.

Ketetapan MPR Nomor IV/MPR/1978 Tentang GBHN dalam https://peraturan.go.id/peraturan/view.html?id=11e458137d1ec49ea9b13030 34323235. Diakses 1 September 2021.

Maarif, S., Mubarok, H., Sahroni, L. F., \& Roessusita, D. (2019). Merangkul Penghayat Kepercayaan Melalui Advokasi Inklusi Sosial: Belajar dari Pengalaman Pendampingan dalam https://issuu.com/programpeduli/docs/ merangkul_penghayat_kepercayaan_melalui_advokasi_i._Diakses 1 September 2021.

Maulana, B., \& Setyowati, N. (2019). Pemenuhan Hak Warga Negara oleh Negara (Studi Akses Pendidikan Kepercayaan bagi Peserta Didik Sekolah Menengah Atas Penghayat Kerokhanian Sapta Darma Cabang Surabaya). 
Kajian Moral dan Kewarganegaraan, 7(1), 196-210.

Mutaqin, Z. Z. (2014). Penghayat, Orthodoxy and the Legal Politics of the State: The survival of Agama Djawa Sunda (Madraisism) in Indonesia. Indonesia and the Malay World, 42(122), 1-23. https://doi.org/10.1080/13639811.2014.870771.

Peraturan Pemerintah Nomor 37 tahun 2007 tentang pelaksanaan UU No. 23 tahun 2006 tentang Adminduk dalam http://disdukcapil.purwakartakab.go.id/home/public/frontend/pdf/PP-NO37-TH-2007.pdf. Diakses 1 September 2021.

Permana, A., Magiman, M. M., Science, F., \& Putra, U. (2021). The Implementation of Educational Learning Services for the Penghayat Kepercayaan. Ilköğretim Online, 20(3), 376-384. https://doi.org/10.17051/ilkonline.2021.03.36.

Permendikbud Nomor 27 Tahun 2016 tentang Layanan Pendidikan Kepercayaan terhadap Tuhan Yang Maha Esa pada Satuan Pendidikan dalam https://www.mlki.or.id/wp-content/uploads/2017/05/Pedoman-ImpelentasiFINAL-2-1.pdf. Diakses 1 September 2021.

Putri, U., \& Pringgowijoyo, Y. (2020). Pemenuhan Layanan Pembelajaran Bagi Siswa Penghayat Kepercayaan Di Wilayah Dinas Pendidikan Kabupaten BantuL. Jurnal Kewarganegaraan, 4(1), 45-53. https://doi.org/10.31316/jk.v4i1.883.

Putusan MK Nomor 97/PUU-XIV/2016 tentang Demi Keadilan Berdasarkan Ketuhanan Yang Maha Esa dalam https://www.mkri.id/public/content/ persidangan/putusan/97_PUU-XIV_2016.pdf. Diakses 1 September 2021.

Ramadhan, Y. (2019). Pemenuhan Hak-Hak Anak Penghayat Kepercayaan Atas Pendidikan melalui Kurikulum Sekolah (Studi Kasus di SMK Negeri 7 Semarang) Skripsi: Universitas Katolik Soegijapranata Semarang. Tidak dipublikasikan.

Sholakodin, A. F. (2018). Implementasi Permendikbud No. 27 Tahun 2016 pada Warga Aliran Kebatinan Perjalanan di Kabupaten Tulungagung dalam http://karya-ilmiah.um.ac.id/index.php/Sosiologi/article/view/66350. 
Diakses 1 September 2021.

Suhadi, Yusuf, M., Tahun, M., Asyhari, B., \& Sudarto. (2015). Politik Pendidikan Agama, Kurikulum 2013, dan Ruang Publik Sekolah. Yogyakarta: Program Studi Agama dan Lintas Budaya, Universitas Gadjah Mada.

Undang-Undang Dasar Republik Indonesia Tahun 1945 Pasal 29. https://www.bphn.go.id/data/documents/pkj_tumbuhnya_aliran_paham_kea gamaan.pdf. Diakses 1 September 2021.

Undang-Undang Republik Indonesia Nomor 23 Tahun 2006 tentang Adminduk Pasal 105 dalam https://www.dpr.go.id/dokjdih/document/uu/ UU_2006_23.pdf. Diakses 1 September 2021. 